\title{
Research on the Construction of Party Construction Platform for Sino-foreign Cooperatively-run College Students
}

\author{
Zhu Weixia ${ }^{1,2, a}$

\begin{abstract}
${ }^{1}$ Institute of international education, Shandong University of Finance and Economics, Jinan, Shandong, China ${ }^{2}$ School of Marxism, Beijing normal university, Beijing, China)

azwx0325@sina.com
\end{abstract}

\begin{abstract}
The party construction work platform is an important "stage" to promote the smooth development of students' party construction work. At present, there are many defects in the platform construction of Sino-foreign cooperatively-run school students' party construction, which has affected the actual effect of students' party construction. Therefore, it is necessary to strengthen the construction of the "main platform" to guide the overall direction of party construction; it is necessary to explore the practice platform to deepen the theoretical study, and practice the purpose of serving the people, too; it is necessary to improve the network platform, to ensure that the party construction play an important role on the whole process of students, allround coverage, too. At the same time, we will strengthen the coordinated operation and construction of the three platforms, and give full play to the political leading role of party construction in sino-foreign cooperatively-run schools.

Keywords: Sino-foreign cooperative education, party construction work platform of university students, Organization platform, Practice platform, Network platform.
\end{abstract}

\section{高校中外合作办学学生党建工作平台建设研究}

朱维霞 $1,2, \mathrm{a}$

${ }^{1}$ 山东财经大学国际教育学院, 济南, 山东, 中国

2 北京师范大学马克思主义学院, 北京, 中国

$a_{\text {zwx0325@sina.com }}$

\section{摘要}

党建工作平台是推动学生党建工作顺利开展的重要 “舞台” ，当前中外合作办学学生党建工作的平台 建设存在很多不够完善的地方，影响了党建工作的实效性。为此，需要加强组织 “主平台” 的建设， 引领党建工作的整体方向; 多方开拓实践平台, 深化理论学习、践行为人民服务的宗旨; 完善网络平 台, 保证党建工作对学生全程、全方位的覆盖。同时, 加强三大平台的协同运作和建设, 充分发挥党 建工作对中外合作办学机构的政治引领作用。

关键词: 中外合作办学; 学生党建工作平台; 组织平台; 实践平台; 网络平台

\section{1. 前言}

百度搜索 “平台” 有多个涵义, 本文研究的党建工 作平台, 取其 “进行某项工作所需要的环境或条件”之 意。加强高校中外合作办学学生党建工作平台的研究, 就是尽可能地利用和创造条件, 搭好 “舞台” , 让工作 人员施展才能, 有力、有序、有效地推动党建工作顺利 开展，取得预期效果。
2. 加强中外合作办学学生党建工作平台建 设的必要性

从意义和作用的角度来看, 党建工作平台也是 党建工作的路径和方式, 是推动党建工作的 “舞 台”。有效的平台和路径, 可以有力推动党建工作 的有序开展, 取得预期效果。当前各高校学生党建 
工作平台主要包括党组织平台、实践平台和网络平台, 三大平台工作内容各有侧重, 在具体运作中能够相辅相 成、形成合力, 推动党建工作有效开展。

\section{1 当前高校中外合作办学党建工作平台运行 现状}

当前不少高校中外合作办学学生党建工作平台虽然 构架完整, 但是其运行机制不够顺畅, 导致党建工作平 台作用发挥有限, 影响了党建工作的实效性, 具体表现 在三个方面。第一, 各级党组织平台开展党建工作的针 对性不强。中外合作办学机构基层党组织在开展党建工 作的过程中很少结合项目学生的特点, 制定相应的计划 和设置相应的内容, 开展的党建工作没有群体针对性; 对国 (境) 外学生的党建工作大多处于无力、无序的状 态。第二, 实践平台流于形式, 教育实践作用有限。在 部分高校, 出现实践和党建工作 “两张皮” 的现象, 为 了落实党建工作而开展的实践活动对党建工作没有任何 促进作用。例如, 有的高校组织党员参加的社会实践和 调研活动, 只是单纯完成团委安排的 “三千计划” , 对 党建工作的促进意义不大。第三, 网络平台的线上管控 不到位, 存在线上线下不同步的现象。部分高校党建网 络内容丰富, 但是对学生后续学习的督促反馈不力, 导 致资源的浪费; 有的高校党建网站内容更新滞后, 使得 线上的教育内容跟不上线下的教育步伐; 有的高校网络 监控不到位, 导致不良信息夹杂其中, 影响教育效果。 鉴于上述现象, 各高校必须高度重视并搭建有效的党建 工作平台, 以此推动各项党建工作的顺利开展。

\section{2 加强高校中外合作办学党建工作平台建设 的意义}

\subsection{1 加强组织平台建设, 能确保党建工作的 正确方向。}

组织平台是党建工作的主平台和指挥中枢, 既引领 理论学习的主方向, 又承担支部建设和队伍培养的重 任。中外合作办学学生党建工作是在基层党组织的有效 领导下, 依托各级党组织对内完善支部建设和学生党员 的教育管理, 对外进行理论宣传、思想动员、與论引 导, 同时又通过组织实践活动、加强网络管控等, 推动 党建工作有序开展。只有把组织平台筑牢建稳, 才能保 证中外合作办学学生党建工作结合项目学生的特点, 围 绕办学治校和立德树人的中心任务开展工作, 充分发挥 党组织的政治核心作用。

\subsection{2 加强实践平台建设, 能有效推动落实 为人民服务宗旨的实现。}

党的宗旨是全心全意为人民服务，学生党建工 作的落脚点是服务师生、服务人民、服务社会，实 现理论向实践的有效转变。实践平台既给学生提供 了践行所学理论的舞台, 实现党建理论的外化; 又 让学生在服务社会、调研社会的实践中加深对党建 理论的深刻认识与领悟, 实现理论的内化与提升。 中外合作办学学生党建实践平台的建设是落实党的 群众路线和实践理论的必要选择。

\subsection{3 加强网络平台建设, 能保持党建工作 的全程覆盖。}

网络平台涵盖的教育信息量大、存储时间长, 可以满足学生随时学习和回看的需要; 网络平台能 够打破地域界限, 可以满足不同地域的学生在线同 步学习、交流的需要; 网络平台让对国外学生全 程、全方位开展党建工作变得容易。打造完善的网 络平台, 可以让学生结合自己的时间和需要, 自 主、自助完成学习任务; 能够保证国内外学生党建 工作的同步性和一致性, 让党建工作覆盖学生大学 生活的各个阶段。

\section{3. 完善三大平台建设, 推动中外合作办学 学生党建工作顺利开展}

党建工作贯穿大学生高校学习的全过程, 是高 校学生工作的重中之重。随着网络技术的快速发 展, 高校学习教育的平台不再直于 “三尺讲坛”, 线上授课、名师课共享等方式不断涌现。尤其是在 全民一致防御新冠病毒疫情的特殊时期, 网课更是 扛起了授课的大旗, 教学的课堂直接搬到了网络平 台上, 教学效果也是有目共睹的。中外合作办学学 生党建工作也要借鉴这些方式, 改变过于依赖课堂 教学和说教的工作方式, 更大规模地搭建和规范网 络平台和实践平台, 保证对国外学生的持续教育, 拓展工作路径, 提高工作效率。

\section{1 依托高校基层党组织主平台, 有效指导 开展学生党建工作}

高校中外合作办学学生党建工作是学院基层党 组织严格执行党中央和高校党委的决定, 充分发挥 政治核心作用, 围绕办学治校、立德树人根本任务 开展工作，是学生党建工作的主平台和 “指挥中 枢”，主要开展面向全体学生的理论教育、思想引 领、與论引导, 学生党组织的建设完善, 学生党员 的考察、培养、教育、管理等。 


\subsection{1 理论学习、思想引领和與论引导是中外 合作办学学生党建工作的重要任务。}

中外合作办学的学生群体大多比较散漫, 不太注重 时事政治和理论学习, 很容易受外方老师的思想影响, 特别是拟出国学生有着被西化的风险。中外合作办学的 党组织要着力领导组织好学生的思想政治教育, 占领意 识形态的主阵地。首先, 基层党组织书记至少要保证每 学期给学生上一次思政课, 加强政治引领和价值导向, 重点加强中国特色社会主义制度优越性、社会主义核心 价值观、中国梦等内容的教育, 增强他们的民族自豪感 和自信心。第二, 把思想政治理论课作为开展学生党建 工作和教育的主要平台。要加强与任课老师的沟通, 结 合学校的整体教学要求和学生的特点, 适当调整思想政 治理论课的内容, 重点加强中国优秀传统文化和中外历 史文化对比、爱国主义等内容教育。第三, 选拔政治 强、业务精的学生工作人员, 持续有效开展党建工作。 学生工作人员是开展学生党建工作的主力军, 要重视他 们政治素养和国际交流业务能力的培养, 经常性对他们 进行理论学习和工作方法培训, 不断提高其党建工作业 务水平。第四, 加强对学生自组织和自媒体的引导管 理, 把它们作为宣传党建知识、开展党建活动的有力支 撑。注重对学生社团、自办刊物和自媒体等的思想引领 和管理, 注重其思想性和政治方向, 严格审核其活动内 容, 重视其影响力和号召力, 发挥朋辈群体的教育示范 作用。

\section{1 .2 学生党支部建设和学生党员发展是推进 学生党建工作的“两架马车”。}

党建工作对内主要是抓好党支部建设和党员的发展 培养工作, 以此为抓手做好全体师生的教育引导工作。

中外合作办学学生党支部建设重点要做好完善制度 建设、规范工作流程、抓好特色活动等几个方面, 建设 政治性强、极富战斗力、号召力、影响力和带动力的学 生党支部, 以此推动学院学生党建工作顺利开展。学生 党支部的制度建设内容前面已经谈及, 中外合作办学学 生党支部建设要重点做好持续教育学习制度和党员密切 联系群众制度, 提升学生党员的政治素养, 有力把学生 团结在周围。进一步规范党支部会议流程和党员发展程 序与步骤, 使得每项工作有章可循、有理可据, 增强支 部工作的规范性和感召力。结合支部和学生特点, 通过 “主题党日”、一对一结对帮扶等形式, 深入学生群 体, 把党建活动和学生活动有效结合起来。

优秀得力的学生党员是开展党建工作的有力抓手。 中外合作办学机构学生党建工作需要面向两个不同国度 和性质的 “双校园”, 大部分高校会出现国外高校党建 工作主体 “失位” 的现象, 党组织和党务工作者无法安 排到位。在这种情况下, 就需要依靠学生党员和入党积 极分子把国外学生的党建工作落实到位。因此, 要着力 做好学生党员的发展培养工作, 以便发挥他们在国内外 党建工作中的主体作用。中外合作办学学生党员的发展
和培养坚持做好 “抓先进、常教育、重示范” ，做 到早发现、早培养。从学生入学之初, 就要善于发 现思想端正、立场坚定、工作积极、群众基础好的 “苗子” , 重点加以引导、培养和考察; 善于选树 品德、学习、工作等领域表现突出的代表, 依托这 部分积极分子, 推动开展各项党建工作。建立完善 党员和入党积极分子长效教育机制, 把集体学习和 个人自学、理论学习与主题实践、定期学习与不定 期学习、思政课教师教学与校外专家讲座、讨论发 言与撰写学习心得等方式相结合, 把学习教育贯穿 大学生活的全过程, 持续提高学生党员的政治觉 悟、理论水平和工作能力。重视学生党员的引领示 范和朋辈引导, 以他们为主体把思政课从课堂延伸 到第二课堂, 举办思想性较强的校园文化活动, 让 党建活动惠及每一个学生; 以海外学生党员和入党 积极分子为抓手, 加强对海外学生的思想引领和教 育管理。

\section{2 开拓实践平台, 助力党建工作平稳落地}

党建工作有其鲜明的政治性和严肃性, 其 “高 大上” 的形象往往让人不敢靠近, 理论宣教的枯燥 性也会让人产生抗拒之心。因此, 党建工作需要更 多地借助实践和活动, 深入基层开展特色活动, 才 能真正落实 “从人民中来到人民中去” , 实现为人 民服务的宗旨。中外合作办学学生党建工作更需要 依托主题教育基地和特色活动, 减轻学生的抗拒 感, 调动他们参与的积极性, 强化爱国主义教育和 社会主义核心价值观教育, 增强党建工作的实效 性。

建立校内党员示范岗, 给学生党员贴上闪亮的 名片。要在广大学生中树立 “有困难找党员” “有 需要找党员” 的观念, 无论身在何处, 遇到问题第 一时间去找党员和党组织求助。很多高校都设有

“共产党员宿舍” “学生党员示范岗” 等, 就是要 充分展示党员的榜样形象, 起到很好的示范引领作 用。也通过这种平台, 给学生党员更多服务师生的 机会, 和学工老师一起开展学生思想引领、学习提 升、日常生活和心理解惑等方面的工作。进一步落 实 “一对一” 帮扶制度, 让一个党员带好一个普通 学生、一个学生宿舍, 实现全覆盖的帮扶。

建立校外党建活动基地, 增强党建工作的形象 性和实效性。开拓党史陈列馆、博物馆、爱国主义 教育基地等校外党建活动基地, 身临其境地追缅历 史、感受革命先辈的奋斗精神和今天幸福生活的来 之不易; 惊叹和震撼于我们今天所取得的巨大成就 和日益强大的国际地位。把党建课堂搬到活动基 地, 把枯燥的理论灌输变为学生主动的感受和体 验, 增强了教育的形象性和说服力, 拉低了学生的 抗拒感, 切实提高党建工作实效。

建立党员实践队, 开展社会实践活动, 把理论 与实践相结合, 进一步增强理论自信和行动自觉。 
与学校安排的社会实践或 “三千计划” 相结合, 组织以 学生党员和入党积极分子为主体的社会实践调研团队, 针对感兴趣的选题, 深入农村、企业一线, 关注民生、 关心民众的幸福指数、加强国际对比, 了解我国在经 济、社会、文化等各方面发生的巨大变化。通过组织社 会调研实践, 让学生在社会大舞台体味我们国家在党的 领导下所取得的巨大变化, 更坚定地拥护中国共产党的 领导、树立民族自信心和自豪感。

开展校内外结对帮扶的公益实践, 培养学生党员和 入党积极分子服务社会、反馈社会的自觉性。国外高校 比较注重对学生实践能力和公益行为的考核, 中外合作 办学的学生要注重自身实践能力和服务社会能力的培 养, 以便以后申请高排位的世界名校继续学业。鼓励学 生去敬老院、福利院、特殊教育机构等单位去做义工, 给农民工的子女进行作业辅导, 兼职社区文明宣讲员 等, 积极参加各种社会公益实践。通过这些公益实践, 既能让他们在服务社会、帮助他人的过程中获得存在 感, 也能充分锻炼他们的实践能力。

\section{3 搭建网络平台, 为学生党建工作全程续航}

随着网络科技的不断发展, 网上课堂所占的比重也 是与日俱增。网络课堂具有资源丰富、随时回看、跨越 时空限制等特点, 给学生提供了随时随地进行学习的平 台, 全方位无死角地进行各种学习。

\subsection{1 网络学习平台为学生的自学提供了有力 支持。}

网络信息具有即时性和长时性并存的特点, 既能做 到同步直播, 把第一手的信息最快传送给各个网络端的 学习者; 又能长时间地保存资源, 保证大家可以多次回 看学习, 巩固学习成果。网络信息资源还具有多样性和 方向性相统一的特性, 针对同一个问题会有多种解读和 论证, 展示方式也具有多样性, 但是殊途同归, 多样性 的存在最终都要指向中央的整体方针, 服务于党建工作 的主题方向。网络平台的这些特点保证了学生可以结合 自己的时间和自身的学习特点, 合理安排自己的学习计 划, 有效提高学习效率。

\subsection{2 网络学习平台打破时空的限制, 持续为 国外学生提供教育与辅导。}

国外学生因为时差和地域问题, 很难与国内的学习 教育同步, 网络平台给国外学生提供了错时学习和同时 研讨的机会。国内党务工作者通过建立专题学习网站、 制作学习课件、录制讲座视频等方式, 把各种学习资源 尽数提供给国外的学生, 依托国外的学生党员、入党积 极分子、学生干部等组织学习、研讨, 撰写心得体会 等, 加强对国外学生的教育指导。有时为了取得更好的
学习效果, 可以选择一个国内外都比较合适的时 间, 通过 qq 群、微信群实时讨论学习, 腾讯会议视 频连线学习等方式, 实现国内外同步学习讨论, 提 高党建工作的实效性。

\section{3 .3 注重对网络教育平台的管控, 尽量避 免负面信息的干扰。}

网络平台丰富了中外合作办学学生党建工作方 式, 也保证了对国外学生进行党建工作的同步性。 但是，网络资源和信息是 “百家争鸣” “百花齐 放”，不良的信息时常夹杂其中，在一定程度上会 混淆视听, 起到误导作用; 西方国家也在利用这个 平台进行意识形态的渗透教育; 因时空的界限问 题, 对国外学生的思想动态和现状无法第一时间掌 握; 学生党员和学生干部开展党建工作的力度和方 式无法及时把控等。如果利用不当, 网络平台教育 反而会起到反作用。所以, 中外合作办学的党建工 作尤其要做好对网络平台的管控, 严把网络资源的 政治关和思想关，加强对党建工作人员的培养和国 外学生党员、学生干部的管理, 让我们的正确思想 和资源占据理论宣传的主阵地, 让党建工作在国内 外学生群体中有效推展下去。

组织平台、实践平台和网络平台同为中外合作 办学学生党建工作的平台, 三者是有机统一的关 系。党组织平台是 “指挥中枢”, 指引党建工作的 整体方向, 整体负责理论的宣传教育和党建活动的 有效组织。实践平台是理论与实践相结合、学校与 社会相结合，积极落实从人民中来到人民中去、全 心全意为人民服务宗旨的平台, 让学生党员在回馈 社会的实践中深刻领悟、掌握党建理论。网络平台 改变了固有的学习教育模式, 让学生可以结合自己 的时间随时随地进行学习, 延伸了党建课堂, 更重 要的是搭建了对国外学生进行教育管理的平台, 让 党建工作得以在海外继续开展。党建工作中要结合 教育内容和学生特点, 有效利用三个平台, 保证党 建工作在中外合作办学学生学习的每个阶段、每个 校园都得到落实。

\section{项目基金}

本文系 2017 年度山东省社科规划（高 校思政专项）项目《中外合作办学学生党 建 工作机制研 究》（项目编号 17CSZJ19），2018 年度山东省社会科学规 划高等学校思想政治教育研究专项课题 《高校思想政治教育工作者与专业教师协 同育人机制研 究》( 项目编号 18CSZJ01），山东财经大学 2019 年度党建 
重点课题《基于目标实现的学院教工党支部与 团学组织协同育人机制研究》（课题编号 scddjkt2019zd009）的阶段性成果。

\section{References}

[1] Yang, L. (2014) Analysis of the education and management of party members of overseas college students. School party building and ideological education, vol.10:48-49.
[2] Zhang, L.M., Lv, J. Sh. (2015), Research on the innovation practice and effectiveness of Chineseforeign cooperatively-run school party construction, Learning theory, vol.4: 92-94.

[3] Zhang, L. Liu, Zh. J. (2018) The exploration and reflection on the construction of the "two-stage" party construction mode for college students in the context of Sino-foreign cooperation. Education and teaching forum, vol.21: 40-41. 